\title{
Challenges Experienced by Kurdish EFL Student-teachers during their Teaching Practicum
}

\author{
${ }^{1}$ Hameed Hussein Hamasaid, , ${ }^{2}$ Beway Mahmood Saheb \\ ${ }^{1,2}$ Department of English Language, College of Basic Education, University of Halabja, Halabja, Kurdistan Region, Iraq
}

Corresponding author's e-mail: hameed.hamasaid@uoh.edu.iq

\begin{abstract}
The aim of this study is to investigate the challenges EFL student-teachers experienced during their six-week teaching practicum. The participants were 20 student-teachers from the University of Halabja/ English Language Department who have participated in the teaching practicum in 2018-2019 academic year. Qualitative data collected from two focused group interviews (10 participants each) concerning the challenges studentteachers have experienced while practicing teaching in the basic schools. Thematic analysis was used to analyze the qualitative data. The themes were identified using generic inductive analysis. The collected data were transcribed, coded and then analyzed. The results revealed that student-teachers faced various challenges during their teaching practice such as lack of technology in the schools, dealing with students with special needs, classroom management, use of $\mathrm{L} 1$ in the classroom, large classes and dealing with students' difficult questions. Based on the results of the study, some recommendations will be made.
\end{abstract}

Key words: Teaching practicum, student-teachers, challenges, Kurdish EFL Learners

\begin{tabular}{|c|c|}
\hline \multicolumn{2}{|c|}{ 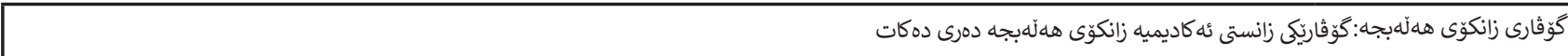 } \\
\hline 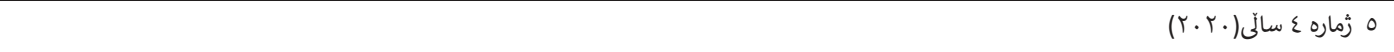 & بهرى \\
\hline 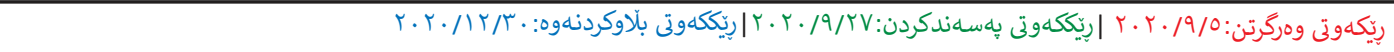 & ريّيكلوتهكان \\
\hline hameed.hamasaid@uoh.edu.iq & ئيمهليلى تويَّرهر \\
\hline 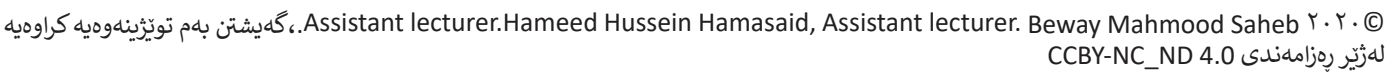 & مافى حاب و بلاو كردنهوه \\
\hline
\end{tabular}




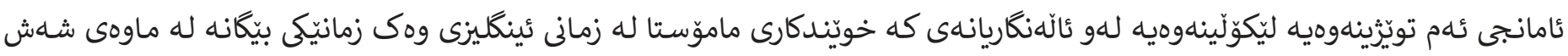

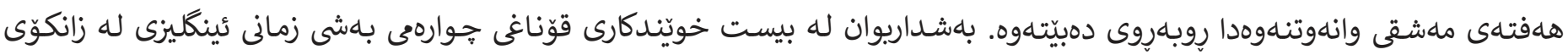

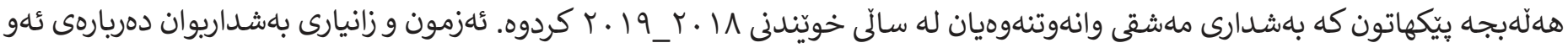

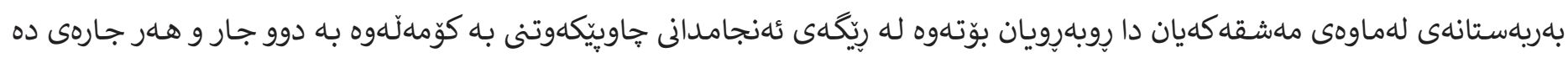

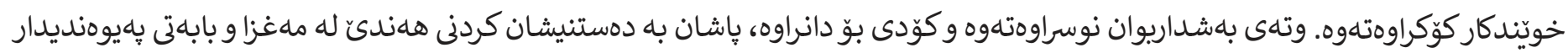

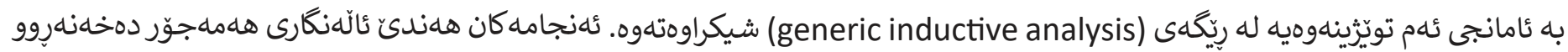

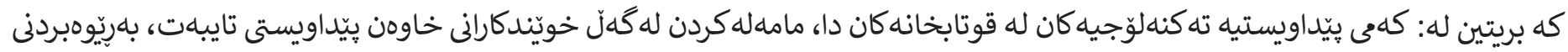

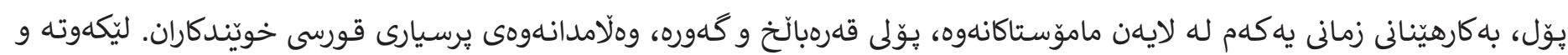

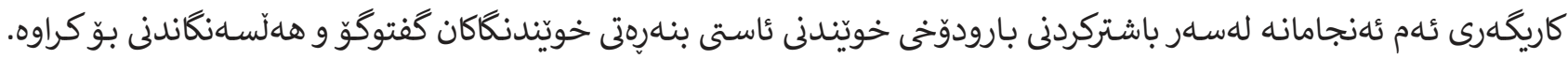

\section{Introduction}

Teaching, like any other profession, requires education and training. Freeman (2001, p.72) points out "teacher education refers to the sum of experiences and activities through which individuals learn to be language teachers". Apart from their formal education, students at the college of basic education need to be provided with opportunity to apply what they have learned at university. At the university level, students spend four years studying various theoretical subjects; however, being able to teach effectively needs more than just knowledge of the subjects, it also needs practical skills. Furthermore, in order to be able to teach effectively and to put the theories into practice, teachers have to gain practical experience through training and practicum. Teaching practicum is aimed to provide student-teachers an opportunity to experience classroom teaching, to put into practice what they have learnt theoretically, and to gain essential pedagogical skills (Richards and Schmidt, 2010).

In the last two decades, teaching practicum has become an essential part of the ESL teacher's Professional development in many TESOL programs (Richards \& Crooks, 1988). Teaching practicum is part of the teacher education programs at many universities as well. Students are sent to schools to experience the reality of teaching, and to gain experience of teaching. According to Richards and Schmidt $(2010$, p. 589) teaching practice or practicum ( in teacher education) is defined as "opportunities provided for a student teacher to gain teaching experience, usually through working with an experienced teacher- the CO-OPERATING TEACHER- for a period of time by teaching that teacher's class". Furthermore, Richards and Crooks (1988) state that teaching practicum is a major opportunity for student-teachers to gain practical skills and experience necessary to function as successful language teachers.

Being a student for many years does not teach you every aspect of teaching profession. Borg (2004) describes the apprenticeship of observation which is a phenomenon whereby student-teachers are taking training courses after spending a great deal of time as pupils and students observing and evaluating their teachers in action. 
However, "student teachers may fail to realize that the aspects of teaching which they perceived as students represented only a partial view of the teacher's job" (Borg, 2004. P. 274). Furthermore, Lortie (1975 cited in Borg, 2004, p. 274) write that a student "sees the teacher frontstage and center like an audience viewing a play". Although students can see what the teachers do in front of the class such as teaching, checking students' understanding and giving feedback, they are not aware of what the teachers do to prepare themselves as teachers before coming to class (ibid). Therefore, teaching practice plays a key role in giving the student-teachers practical experience of classroom. According to the results of a survey conducted by Richards and Crooks (1988: 9) regarding the most important objectives of teaching practice in which the participants were asked to rank eight objectives in order of importance, the results were as follows:

1. To provide practical experience in classroom teaching

2. To apply instruction from theory course

3. To provide opportunities to observe master teachers

4. To give feedback on teaching techniques

5. To develop increased awareness of personal teaching style

6. To develop lesson planning skills

7. To develop ability to select/adapt materials

8. To become familiar with specific methods (e.g. the Silent Way) (Richards and Crooks,1988, p. 11)

In order to acquire skills of teaching, student-teachers need to experience the reality of teaching in classroom; they may face various challenges in this regard. Richards (2011) states that, the first challenge non-experienced teachers face is to make an attempt to gain essential classroom skills to present their lessons' ability and performance. Researchers report various reasons for these challenges student teachers face during their teaching practice. According to Vaughn, Bos \& Schumm (1997) non-experienced teachers recounted that their undergraduate programs do not fully equip them with skills to face the challenges of classroom such as large classes, students who do not speak in English, students with special needs, and students with no sufficient support from their families. Furthermore, Pugach (1992) states that beginning teachers are apprehensive and vulnerable, and they lack confidence in the first years of their teaching.

The present study investigates the specific challenges student-teachers from the English Department at the University of Halabja encounter during their teaching practicum. It is also an attempt to identify the gap between what they have studied and what they need in the real teaching context. The findings of the study are important to provide insights into the way we design the curriculum and the program of the English Department. 


\section{Relevant Previous Studies in Different Contexts}

Concerning the problems, challenges and difficulties student-teachers face during their teaching practice, a considerable number of researches have been conducted in various contexts. A study conducted by Veenman (1984) viewed 83 previous studies from different countries from 1960 -1983 regarding the perceived problems the beginning teachers faced. The results show that beginning teachers encountered eight major problems among them are classroom discipline, dealing with individual differences, inadequate teaching materials and supplies, and dealing with problems of individual students. Sariçoban (2010) conducted a quantitative study in which 118 student-teachers participated from different school levels. He focused on researching the problems student-teachers face with reference to teaching materials and equipment, academic course-books, students, curriculum, and classroom setting. He concluded that lack of the internet and other modern equipment is suffered by the student-teachers and there were also problems in motivating students to participate in activities especially in large classes. In the Kurdish context, a recent study conducted by Abdulrahman (2019) which investigated the challenges student teachers faced at the College of Basic Education-University of Sulaimani. The study adopted quantitative method and the data collected using a questionnaire. 50 student-teachers participated in the study. The results revealed that student-teachers faced challenges such as paucity of motivation of pupils in the basic schools, the short duration of the teaching practicum, assessors' evaluation and the shortage of technological tools.

Furthermore, another study conducted by Okobia and Osagie (2013) at the University of Benin/ Nigeria. Two hundred student-teachers participated in the study which was about 'perceived challenges faced by student teachers'. According to the results of the study student-teachers faced many challenges in their teaching practicum. The major challenges were insufficient teaching practice orientation, lack of instructional materials, and poor interpersonal relationships between faculty members and student teachers. Gan (2013) conducted a study to investigate the challenges pre-service non-native speaker teachers faced during their teaching practicum. The pre-service teachers were from Bachelor of Education (English department) in Hong Kong. The results of the study show that they experienced some real challenges such as difficulties in experimenting with pedagogical practices, paucity of control in class, and lack of competence in English language which affected their teaching performance and their role as teachers.

\section{Teacher Education Program Structure}

The program of study at the department of English-College of Basic Education of University of Halabja is designed to equip the students with skills and knowledge they need to function as language teachers once they graduate from university. The courses they take during the four years at university include language skills, linguistics, English literature, applied linguistics, psychology, teaching methodology, class observation and teaching practice. Through these courses, students will improve their language skills, gain knowledge about various 
sub-categories of linguistics and psychology, and methods of teaching. In the final year of their education, students take a compulsory course which is called Observation and Teaching Practice. In this course, students spend 8 weeks (one day per week) observing classes in one of the basic schools. In the second part of this course senior students usually spend 6 weeks in the basic schools experiencing the reality of classroom and teach actual classes. During this period of time, student-teachers teach English subject of grades 1 to 9.

\section{Research Question}

This research seeks to answer the following question:

What are the major challenges the Kurdish EFL student-teachers face during their teaching practicum?

\section{Research Methodology}

\section{The Participants and Context of the Teaching Practicum}

The two focus group participants for this study were 20 undergraduate students (seniors) of Department of English Language-College of Basic Education at the University of Halabja. As mentioned previously, part of the Department of English program is the practicum in which student-teachers practice teaching in the Basic schools (1-9 grades). Fourth year students (seniors) at the College of Basic Education are required to spend 6 weeks practice teaching at one of the basic schools. The new context is completely challenging for the studentteachers since they have not been there as teachers before. During their practicum, students-teachers will be allowed to plan and teach lessons in different grades. They need to carefully plan comprehensive lessons and stand in for other experienced teachers. During this time, each student-teacher is assigned two assessors from faculty members of their university to observe and assess their performance both educationally and scientifically. The two assessors usually visit the student-teacher on two different days; one of the assessors is focusing on the educational aspects of the teaching, whereas the other one is assessing the scientific aspects of the lesson.

\section{Data Analysis}

Focus Group Discussions (FGDs) were used to collect the data for this research. Advanced preparation has been made to the focus group interviews. The interviews took place at the University of Halabja, and they were moderated by the researchers and lasted for about fifty minutes each. The interviews were conducted in English language because the participants were senior students and they had a good command in English. 20 students (those who were interested) were selected to participate in the study. The data were collected from two focused group discussions. 10 females and 10 males were interviewed separately in two FGDs. Male and female student-teachers were purposefully invited to participate in the study to see whether there is any significance difference between the challenges each gender might face. Thematic analysis was used to analyze the qualita- 
tive data. The themes were recognized using generic inductive analysis (identify themes through analyzing the transcript of the recordings) (Hood, 2007). The collected data were transcribed, coded and then analyzed.

\section{Results}

After transcribing the recorded FGDs, coding and analyzing them, themes were identified as challenges faced by student-teachers during their teaching practicum. The data analysis revealed 6 themes across the two FGDs concerning the challenges which were (a) lack of technology, (b) larges classes, (c) dealing with students with special needs, (d) controlling the students, (e) using L1 in class, and (f) dealing with difficult questions by the students.

\section{Lack of Technology}

Nowadays, technology has permeated every aspect of life. Technology plays a vital role in education and is used widely in educational settings around the world. However, from the accounts of most of the participants of the study it is evident that lack of technology was one of the challenges they faced during their teaching practice. Lack of technology affected their teaching style.

"...[lack of technology] restricted us from using various materials".

One of the participants reported that the course book activities required some kind of technology. "... We had to use pictures, videos, but the schools did not provide these technological tools, they even did not provide a speaker, so we had to skip those activities".

Some of the participants reported that students were interested in a class in which teachers use technology. "...the new generation do not like the traditional way of teaching, only using the board and the marker? They are interested in using technology for learning. Unfortunately, we were not able to do that for them in class". This shows that the public schools still lack essential technological tools which pose challenges for both teachers and student-teachers.

\section{Large Classes}

According to the majority of the responses dealing with large class sizes was one of the challenges studentteachers faced. Participants reported that there were many students in the class and this presented a major challenge for them.

"The number of the students was the biggest challenge for me; it was too difficult to control them. For example, in one of the classes I had 47 students. It was also too difficult to manage them".

Most of them reported that having a lot of students in the class posed difficulties for them to manage the class.

"One of the problems I faced there is a lot of students in the class. When there are a lot of students, it is too difficult to manage them". 


\section{Students with Special Needs}

On the basis of the data collected from the FGDs, it seems that handling students with disabilities was a major challenge for the student-teachers. Some of the respondents addressed the issue of handling students with special needs. They pointed out that they had students with special needs in the classes they taught, and this posed a real challenge for them. These students were mixed with other students and it was difficult to control them.

"One of the students had Down's syndrome, and I had no idea how to handle him".

According to one of the participants, the student-teachers were not even told or informed in advance that there were students with special needs in the classes, and they were not even told what type of issues they have.

"There were students with special needs." "I had a student who had mental disease". "Actually, I didn't know what type of disease it was". "He would beat other students." "I didn't know how to deal with this." Another participant said:

"I had a deaf student. She couldn't hear and speak. I didn't know this until other students told me that."

\section{Classroom Management}

Lack of control was another challenge student-teachers faced during their practicum. All of the participants reported that dealing with students' misbehavior was somehow difficult for them and sometimes they did not have any idea how to deal with it.

"The second challenge was controlling the class especially the messy ones." "I wanted to create a friendly atmosphere for them, but they were not easy to control."

Some of the student-teachers reported that sometimes the age of the students made the situation even worse. "Their age is very sensitive; you need to treat them in a very special way." "Their mindset and behaviors are different." "You have to choose a very special way to deal with them."

Some of the female student-teachers revealed that the male teenagers did not conform to the class regulations as they thought they were more powerful than the female teachers.

"They were mixed, boys and girls." "Some of them were taller than me. They wanted to show that they have power on me."

Student-teachers also revealed that they learned that the school teachers would sometimes beat the students to control them.

"I was shocked when I realized that their teachers hit the students to control them."

"Their own teachers could not control them." "They used bad words with them."

"The students were moving a lot." "They came to me in the middle of the class."

"One of the students said you have to beat us. If you do not beat us, we are not gonna be quiet. That was really 
something weird to me."

\section{Using L1 in the Class}

One of the challenges that almost all of the respondents of the study reported is that L1 of the students (Kurdish in this case) has been used as the main language of class instruction by the teachers of the school, and this posed challenges for those student- teachers who were willing to use English as the main language in the class. One of the student-teachers reported that

"All of them (pupils) spoke in Kurdish because their teachers were teaching them only in Kurdish."

Student-teachers stated that the pupils got used to use Kurdish in class because they said their teachers had used Kurdish in the class not English. This is challenging for the student-teachers who are willing to use more English in the class.

"You know the aim of English lesson is to teach English. Unfortunately, we could not use English because they [pupils] were not able to understand, so I had to use Kurdish and this made me uncomfortable."

\section{Difficult Questions by Knowledgeable Students}

Having knowledgeable students in the class was another challenge for the student-teachers. Students teachers pointed out that they had students who were asking too many questions in the class and sometimes they were embarrassed because of not being able to answer them.

“...the level of some students was really high. Sometimes they asked me difficult questions. Or they asked me the meaning of difficult words. I had student who were very smart. They had a lot of information. So, I had to prepare myself well..."

“...there were students who were very intelligent. They would sometimes correct my pronunciation mistakes. I felt a shamed. Or they asked me the meaning of difficult vocabulary. I didn't know them..."

\section{Discussion}

According to the results of the study, student-teachers were in agreement that the teaching practice was challenging, and the new environment was, to some extent, intimidating for them. Some of the challenges were not expected by the student-teachers. Teaching practice has given the student-teachers invaluable experience; however, they encountered real challenges. The challenges were identified as lack of technology in classes, using $\mathrm{L} 1$ in the class, large classes, students with special needs, controlling the students and dealing with difficult questions.

Concerning technology in this early part of twenty first century, it is obvious that technology plays a crucial role in educational settings. There are various classroom technological devices and their uses have become "central to language practice" (Motteram, 2013, p. 5). Therefore, lack of technology poses challenges for student-teach- 
ers and experienced teachers as well. This is in agreement with the findings of two studies mentioned earlier by Veenman (1984) and Sariçoban (2010). As presented earlier, most of the student-teachers found this challenging as they reported that the classes in which they were practicing lacked technological tools. As a result of this, they had to skip activities and tasks which required the use of technological tools. Therefore, this will limit the diversity of activities in class.

Although new researches support the idea of using L1 judiciously (only for specific purposes) would facilitate learning L2, there was once an idea that only English should be used in class in order to provide the students with maximum exposure (Krashen1981; Ellis, 1989). Using L1 and its role in second language classes have been one of the issues in the field of English Language Teaching. English only policy was adopted in classes once; however, recently conducted researches have proven the advantageous role of judicious use of L1 in L2 classes. In other words, using L1 for specific situations is worthwhile. However, using too much L1 in classes outweighs the advantages. This was one of the major challenges student-teachers faced during their teaching practice. The student-teachers reported that school teachers and students still use L1 as the main language in the class which is in line with the same finding by Merc (2010). This had posed real challenges for them as they were trying to adopt new methodology which necessitated the use of $L 2$ as the main language of class. This means that using or avoiding L1 is still a real issue in Kurdish EFL classes. However, according Freeman (2011) using L1 wisely for some specific situations like explaining the meaning of a difficult vocabulary or grammar point is useful and it saves time.

Dealing with students with special needs was also challenging for some of the student-teachers. One of the challenges student-teachers faced was that they were not well prepared to provide for students with special disabilities. Again, this is in line with findings of Vaughn, Bos \& Schumm, (1997) mentioned in the previous studies section. Student- teachers were not able to help those students because they did not expect to face such challenges and they were also not engaged in training related to special education before. Since the public schools specifically in Halabja city mix students with special needs with other students, providing training courses for student-teachers in the teacher education programs is really essential.

Teaching large classes pose challenges for teachers (Hess, 2001). Hess describes the feeling of teachers, in this type of classes, who feel "trapped in the problem of management" and "out of control" (2001, p.4 and 5). The situation becomes worse when teachers realize that they cannot respond to individual ways of learning. Furthermore, having some more knowledgeable students in these classes is also challenging for teachers. This leads to the dominance of knowledgeable students who sometimes challenge the teachers by asking questions that seem difficult to answer. This is the last thing that every teacher, experienced or non-experienced, wishes to see in his or her class. 


\section{Conclusion}

This study investigates the challenges Kurdish EFL student-teachers encounter during their teaching practice in public basic schools in Iraqi Kurdistan region. The major challenges for the targeted group have been identified in a qualitative study using focused group interviews. The thematic analysis was carried out, and thus six common challenges were identified: lack of technology, large classes, dealing with students with special needs, controlling the students, using L1 by the teachers, and difficult questions of knowledgeable students. The findings indicate that Kurdish EFL student-teachers need more theoretical knowledge with regard to the various aspects of classroom management as well as hands-on experience to cope with the essential classroom issues mentioned earlier. It appears that the challenges are interrelated and are more connected to the issues of classroom management, and these challenges have the potential to exacerbate the teaching experience of the student-teachers who are already going through a tough time.

\section{Recommendations}

These steps can be recommended to meet the challenges the student-teachers faced in their teaching practicum. As per the findings of the study, the program of study at the English Department- College of Basic Education must put more emphasis on the aspects of teaching which deal with classroom management issues, and incorporate trainings to deal with students with special needs. Further, as the findings of the study revealed, the basic schools lack basic educational resources. Therefore, more technological tools are needed to improve and facilitate the process of teaching and learning in the basic schools.

\section{References}

Abdulrahman, B. S. (2019). Kurdish EFL Students Teachers' Practicum Experience: Some Basic Challenges. Journal of University of Human Development, 5(2), 13-19.

Borg, M. (2004). The apprenticeship of observation. ELT journal, 58 (3), 274-276.

Ellis, R. (1989). Understanding second language acquisition (Vol. 31). Oxford: Oxford University Press.

Freeman, D. (2001). Second language teacher education. In R. Carter \& D. Nunan (Eds.), The Cambridge guide to teaching English to speakers of other languages (pp. 72-79). Cambridge: Cambridge University Press.

Freeman, D. (2011). Techniques and principles in language teaching. Oxford: Oxford University Press.

Gan, Z. (2013). Learning to teach English language in the practicum: What challenges do non-native ESL student teachers face?. Australian Journal of Teacher Education, 38 (3), 92-108.

Hess, N. (2001). Teaching large multilevel classes. Cambridge: Cambridge University Press.

Hood, J. C. (2007). Orthodoxy vs. power: The defining traits of grounded theory. The Sage handbook of grounded theory, 151-164.

Krashen, S. D. (1981). Second language acquisition and second language learning. Pergamon Press Inc., Oxford. 
Merc, A. (2010). Self-reported problems of pre-service EFL teachers throughout teaching practicum. Anadolu University Journal of Social Sciences, 10 (2),199-226.

Motteram, G. (Ed.). (2013). Innovations in learning technologies for English language teaching. London: British Council.

Nunan, D., \& Carter, R. (Eds.). (2001). The Cambridge guide to teaching English to speakers of other languages. Cambridge: Cambridge University Press.

Okobia, E. O., Augustine, O. E., \& Osagie, R. O. (2013). An analysis of the perceived challenges aced by studentteachers during teaching practice exercise. Journal of Education and Practice, 4(11), 7-11.

Pugach, M. C. (1992). Uncharted territory: Research on the socialization of special education teachers. Teacher Education and Special Education, 15(2), 133-147.

Richards, J. C. (2011). Competence and performance in language teaching. Cambridge: Cambridge University Press.

Richards, J. C., \& Crookes, G. (1988). The practicum in TESOL. Tesol Quarterly, 22(1), 9- 27.

Richards, Jack C. \& Farrell, Thomas S. C. (2011). Practice teaching: A reflective approach. Cambridge: Cambridge University Press.

Richards, J., \& Schmidt, R. (2010). Longman dictionary of language teaching and applied linguistics. London: Routledge.

Sarıçoban, A. (2010). Problems encountered by student-teachers during their practicum studies. ProcediaSocial and Behavioral Sciences, 2(2), 707-711.

Stuart, C., \& Thurlow, D. (2000). Making it their own: Preservice teachers' experiences, beliefs, and classroom practices. Journal of teacher education, 51(2), 113-121.

Vaughn, S., Bos, C. S., \& Schumm, J. S. (1997). Teaching mainstreamed, diverse, and at-risk students in the general education classroom. Boston: Allyn \& Bacon Inc.

Veenman, S. (1984). Perceived problems of beginning teachers. Review of educational research, 54(2), 143178. 